\title{
Research Article: Study on inter-granular temperature and grain moisture changes during deep bed drying of high moisture paddy
}

\author{
ANARASE DATTATRAY ARJUN, S. GANAPATHY, ARUN PRASATH, T. \\ PANDIARAJAN, K. BHUVANESWARI AND M. DURAISAMY
}

Article Chronicle: Received :

15.07.2017;

Accepted :

30.07.2017

KeY Words:

High moisture paddy, Drying bin, Deep bed, Temperature,

Moisture

Author for correspondence : ANARASE DATTATRAY ARJUN

Department of Food and Atricultural Process

Engineering, Tamil Nadu Agricultural University, COIMBATORE (T.N.) INDIA

Email : d.anarase@ gmail.com

See end of the article for authors' affiliations
SUMMARY :Grain moisture and temperature changes during drying of high moisture paddy in pilot scale deep bed drying bin was studied. Drying trial was conducted at inlet air temperature: $40^{\circ} \mathrm{C}$ and air flow rate: $0.4 \mathrm{~m}^{3} \mathrm{~s}^{-1} \mathrm{~m}^{-2}$ in $90 \mathrm{~cm}$ deep cylindrical drying bin. Varying ambient temperature caused the fluctuation of bed temperatures in bottom, middle and top layer of the bin. High values of air relative humilities in drying bin were observed throughout the drying trial. Moisture differential between bottom and top layer was 5\% at end of drying experiment. Paddy in bottom layer dried faster than middle and top layer of the bin. These findings are important in view point of formulating the operating strategies for blower, selection of air flow rate and depth of grains in drying bed to achieve the uniform drying in deep bed dryer.

How to cite this article : Arjun, Anarase Dattatray, Ganapathy, S., Prasath, Arun, Pandiarajan, T., Bhuvaneswari, K. and Duraisamy, M. (2017). Study on inter-granular temperature and grain moisture changes during deep bed drying of high moisture paddy. Agric. Update, 12(TECHSEAR-5) : 1367-1370; DOI: 10.15740/HAS/AU/ 12.TECHSEAR(5)2017/1367-1370. 